\title{
Calibration of the hydrological model GR4J from potential evapotranspiration estimates by the Penman-Monteith and Oudin methods in the Ouémé watershed (West Africa)
}

\author{
Domiho Japhet Kodja ${ }^{1}$, Arsène J. Sègla Akognongbé ${ }^{1}$, Ernest Amoussou ${ }^{1,2}$, Gil Mahé ${ }^{3}$, \\ E. Wilfrid Vissin ${ }^{1}$, Jean-Emmanuel Paturel ${ }^{3}$, and Constant Houndénou ${ }^{1,4}$ \\ ${ }^{1}$ University of Abomey Calavi (Bénin)/Laboratory Pierre Pagney, Climate, Water, Ecosystems and \\ Development (LACEEDE) 03 BP 1112 Cotonou, Republic of Benin \\ ${ }^{2}$ University of Parakou (Bénin), Department of Geography and Spatial, Parakou, Republic of Benin \\ ${ }^{3}$ University of Montpellier, IRD, UMR 5569 HSM HydroSciences Montpellier, France \\ ${ }^{4}$ Institute of Geography, Spatial Planning and the Environment (IGATE), Abomey-Calavi, Republic of Benin
}

Correspondence: Domiho Japhet Kodja (japhdom@gmail.com)

Published: 16 September 2020

\begin{abstract}
The Ouémé watersheds at Bétérou and Bonou has been recently facing increased sensitivity to extreme hydroclimatic phenomena that occurred by flooding or drought events. In the same time, the population growth and the related socio-economic activities increased the pressure state on water resources. In this context, hydrological modeling is an important issue and this study aims at analyzing the calibration of the hydrological model GR4J based on PET Penman-Monteith and Oudin methods. Daily rainfall, Penman-Monteith and Oudin evapotranspiration and daily data flow from the Bétérou and Bonou hydrometric stations on the Ouémé Basin have been implemented in the GR4J model over the period 1971 to 2010. Oudin PET values are slightly higher than the Penman-Monteith PET ones. However, the difference between the two PET methods have only few impacts on the optimization and performance criteria of the GR4J model. The Nash values ranges from 0.83 to 0.91 in Bonou, and 0.52 to 0.70 in Bétérou for the calibration in dry period, while in validation, they are 0.59 to 0.78 in Bétérou, and 0.56 to 0.88 in Bonou in wet season. In view of these results, with the two PET methods used which do not result from the same climatic variables, it should be said that the formulation of PET has only few impacts on the results of GR4J for these tropical basins.
\end{abstract}

\section{Introduction}

The ongoing climatic changes are one of the factors responsible for the recurrence of extreme rainfall anomalies generating risks of flood and drought (Amoussou et al., 2015). Crétat et al. (2012) indicated that due to climate change, the intensity and frequency of heavy rainfall will increase in the future with impacts on groundwater and surface water resources. To predict the availability of these resources is essential for adapted solutions to development projects (Sighomnou, 2004). Rainfall-runoff models are good tools to define the use of water resources by reproducing flows at the basin scale from the measurements or the simulation of rainfall and PET (Afouda et al., 2015). For Paturel et al. (2003) a rainfall-runoff model is more interesting in developing countries because they can be used to estimate the resource available and also its evolution over time by combining it with climate scenarios. Choosing the efficient rainfall-runoff model to reproduce the flows depends on the available input data. Oudin (2004), indicated that sensitivity analysis is considered an important phase of the modeling process. Andréassian et al. (2004) studying the impact of the PET on the parameters and the performances of GR4J and TOPMO models, showed that the models' efficiency was very few influ- 
enced by the choice of the PET formula. In Benin, many hydrological modeling have been carried out with GR4J and GR2M (Vissin, 2007; Amoussou et al., 2015; Afouda et al., 2015). However, these authors did not focus their research on the type of PET methods relevant to the calibration of hydrological model. We thus question in this study the influence of the PET method on the performances of the GR4J model. We test two methods of PET estimation: Penman-Monteith and Oudin, in two sub-catchments of the Ouémé River, Bétérou in the upper catchment and Bonou at the outlet.

\subsection{Geographic location of the study environment}

The Ouémé watershed at Bonou outlet, covers an area of $46200 \mathrm{~km}^{2}$ (41\% of the Benin area); it spreads in its northern part on Dahomeen basement, and on sedimentary ones in the South. Some parts of the basin are in East of Nigeria, and West of Togo (Fig. 1), (Le Barbé et al., 1993).

The climatic structure of Ouémé watershed is presented as follows: in the south is under subequatorial climate with fourseasons alternatively wet and dry (at the outlet of Bonou), and in the north a Sudanian climate with a single-rain-season (at the outlet of Bétérou). In the central part, there is an intermediate climate of sub-sudanian type, transitional climate between the South and the North of the area. The Ouémé River is flowing from North to South along $510 \mathrm{~km}$ on the Beninese territory.

\section{Data and methods}

\subsection{Data}

We used daily rainfall recorded at 30 stations including 4 synoptic ones from the National Direction of Meteorology (NDM) database, related to the ASECNA, Agency for Aerial Navigation Safety in Africa and Madagascar. We use daily flows measured at the outlet of Bonou and collected from the Hydrology Department of the General Direction of Water (DGEau) of Benin. These data cover the years 1971 to 2010 and have been supplemented by the SIEREM/HSM database (Boyer et al., 2006).

\subsection{Methods}

We choose rainfall stations with less than $5 \%$ lacks (Amoussou et al., 2015), with regionalization by the Thiessen method. We test the stationarity rupture probability using statistical tests of the Khronostat 1.01 software, developed by HydroSciences Montpellier laboratory (Boyer et al., 2006).

\subsubsection{Calculation method for evapotranspiration}

PET is not a measured variable, such as rain, but the result of a model combining various climatic variables (Oudin, 2004). In hydrology and especially in rain-flow modeling, the Penman (or Penman-Monteith) model is the most used. This ap- proach nevertheless requires the collection of climate data. If the data collection does not allow a Penman PET calculation, several other formulas can be used to determine the PET. The choice of the formula is then based on the adequacy of the data needed to calculate the PET and the data available. In the case of this study, we highlighted the Penman Monteith PET and the Oudin PET.

\section{Potential Evapotranspiration of Penman-Monteith}

Several methods are used to calculate Potential Evapotranspiration (PET). In hydrological modeling, the PenmanMonteith evapotranspiration estimation method is used (Allen et al., 1998). It requires several climatic parameters including the air temperature ( $\min$ and $\max$ ), the average relative humidity, the insolation, the wind speed at $2 \mathrm{~m} \mathrm{~s}^{-1}$ of the ground, the latitude of the climatological station considered. The remaining data is generated by the software. The software Instat + is used to calculate the PET. It is obtained by the formula below Eq. (1):

$\mathrm{ET}_{0}=\frac{0.408 \Delta\left(R_{\mathrm{n}}-G\right)+\gamma \frac{900}{T+273} U_{2}\left(e_{\mathrm{s}}-e_{\mathrm{a}}\right)}{\Delta+\gamma\left(1+0.34 U_{2}\right)}$

with: $\mathrm{ET}_{0}$ reference evapotranspiration $\left(\mathrm{mm} \mathrm{d}^{-1}\right), R_{\mathrm{n}}$ net radiation at the surface $\left(\mathrm{MJ} \mathrm{m}^{-2} \mathrm{~d}^{-1}\right), G$ soil heat flux density $\left(\mathrm{MJ} \mathrm{m}^{-2} \mathrm{~d}^{-1}\right), T$ mean temperature daily air at $2 \mathrm{~m}$ in height $\left({ }^{\circ} \mathrm{C}\right), U_{2}$ wind speed at $2 \mathrm{~m}$ in height $\left(\mathrm{m} \mathrm{s}^{-1}\right), E_{\mathrm{s}}$ saturation vapor pressure $(\mathrm{kPa})$, and the actual vapor pressure $(\mathrm{kPa})$ These are the saturation vapor pressure deficit $(\mathrm{kPa})$, the slope of the vapor pressure curve $\left(\mathrm{kPa}^{\circ} \mathrm{C}^{-1}\right)$, the psychometric constant $\left(\mathrm{kPa}^{\circ} \mathrm{C}^{-1}\right)$.

\section{Potential Evapotranspiration of Oudin}

The method of Oudin has been used by other researchers (Kay and Davies, 2008; Amoussou et al., 2015). This method of PET calculating comes from the Jensen-Haise and McGuinness models (Amoussou et al., 2015). These models generally used in climatology take into account only the average daily temperature of the air and the solar radiation which depends on the latitude and the $365 \mathrm{~d}$ of the year. Potential Evapotranspiration is obtained by the formula Eq. (2):

$\mathrm{PE}=\frac{R_{\mathrm{e}} T_{\mathrm{a}}+K_{2}}{\gamma_{\rho} K_{1}}, T_{\mathrm{a}}+K_{2}>0, \quad \mathrm{PE}=0$

with PE: Potential Evapotranspiration $\left(\mathrm{mm} \mathrm{j}^{-1}\right) ; R_{\mathrm{e}}$ : Solar radiation $\left(\mathrm{MJ} \mathrm{m}^{-2} \mathrm{~d}^{-1}\right) ; T_{\mathrm{a}}$ : Average daily temperature $\left({ }^{\circ} \mathrm{C}\right)$; $\gamma$ : the latent heat flow $\left(2.45 \mathrm{MJ} \mathrm{kg}^{-1}\right) ; \rho$ : the density of the water $\left(\mathrm{kg} \mathrm{m}^{-3}\right) K_{1}\left({ }^{\circ} \mathrm{C}\right)$ and $K_{2}\left({ }^{\circ} \mathrm{C}\right)$ : are fixed parameters of the model. 


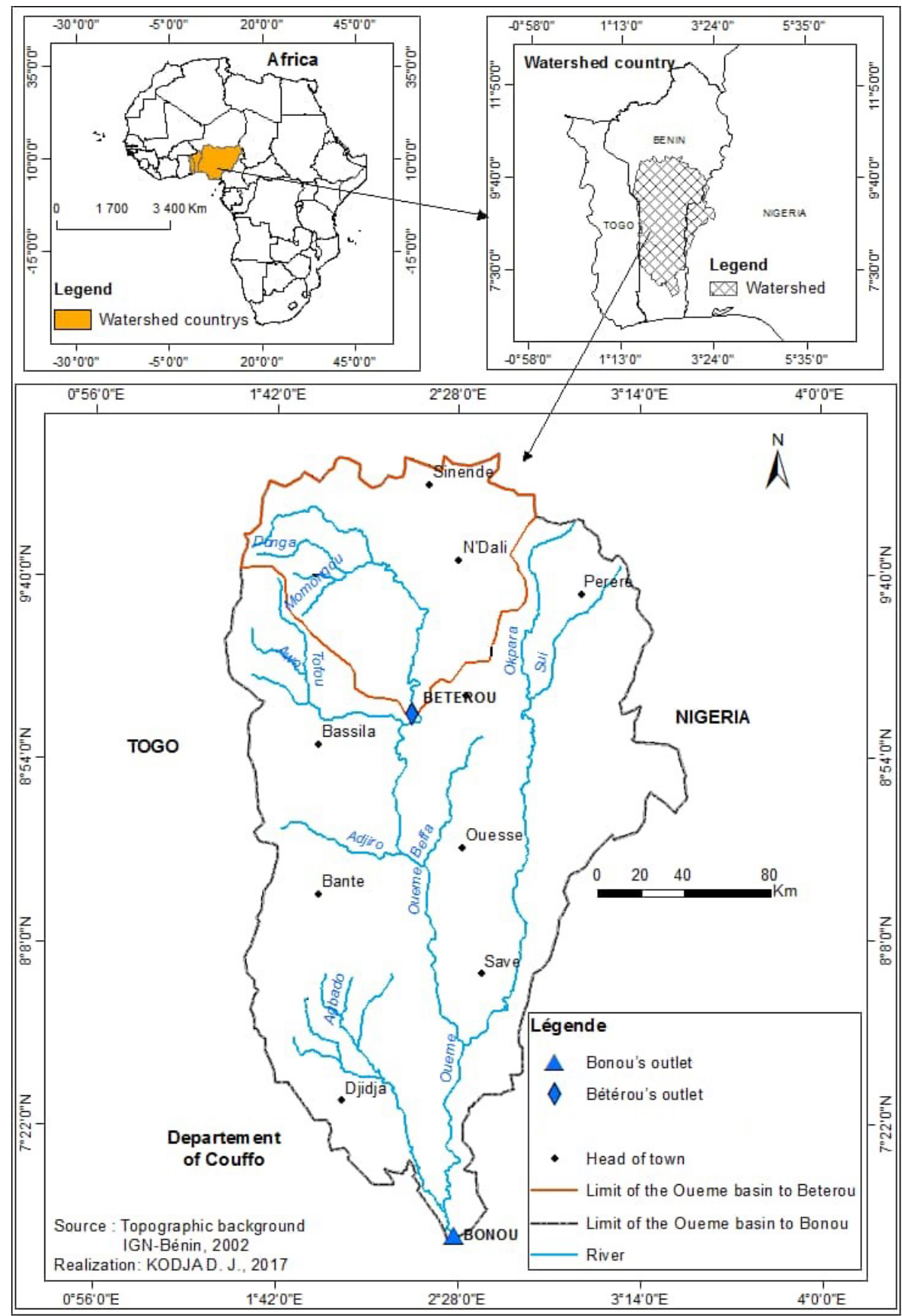

Figure 1. Geographical location.

\subsection{GR4J Hydrological Model}

The GR4J is a global conceptual rainfall-runoff model applied with only four parameters, at a daily time step and using few variables (Perrin et al., 2003). The GR4J model makes it possible to obtain the simulation of daily flows in a hydrological basin, to carry out the forecast of floods and low water levels, to reproduce the functioning of the basin and to obtain the interpolation and extrapolation of the climatic conditions of the basin (Perrin et al., 2003).

\subsubsection{Method of calibration/validation of the model}

To calibrate and to validate the GR4J model, it has been retained two sub-periods (calibration: 1971-1987; validation: 1988-2010). The homogeneity of these sub-periods will be 


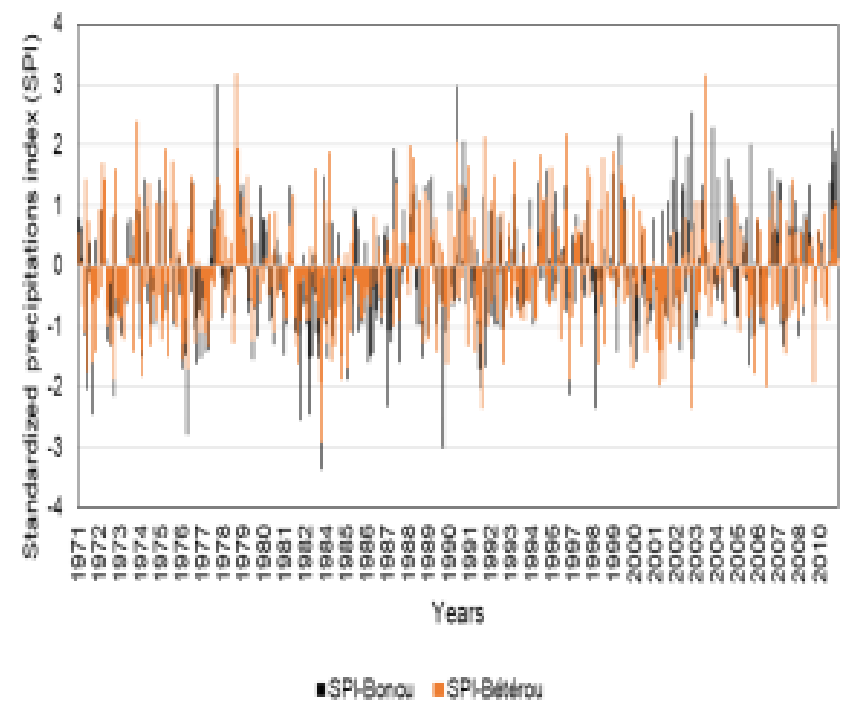

Figure 2. Rainfall index at Bétérou and Bonou (1971-2010).

discussed through the stationarity rupture analysis in the rainfall and flow chronicles.

\subsubsection{Quality criteria of calibration and validation performances}

The calibration of the GR4J model is based on the criteria of optimization and performance of the model to reproduce the flows with the criteria of Nash-Sutcliffe (1970) designated by NSE and whose formulas are Eq. (3):

$\operatorname{NSE}(Q)=\frac{\sum\left(Q_{\text {sim }}-Q_{\mathrm{obs}}\right)}{\sum\left(Q_{\mathrm{obs}}-Q_{\mathrm{obs}}\right.}$

calculated on high water flows;

$\operatorname{NSE}(\sqrt{Q})=\frac{\sum\left(\sqrt{Q_{\text {sim }}}-\sqrt{Q_{\mathrm{obs}}}\right)}{\sum\left(\sqrt{Q_{\mathrm{obs}}}-\sqrt{Q_{\mathrm{obs}}}\right)}$

calculated on average flows;

$\operatorname{NSE}\left(\ln (Q)=\frac{\sum\left(\ln \left(Q_{\text {sim }}\right)-\ln \left(Q_{\text {obs }}\right)\right)}{\sum\left(\ln \left(Q_{\text {obs }}\right)-\ln \left(Q_{\text {obs }}\right)\right)}\right.$

calculated on low flow.

These 3 quality criteria are used in this study and all their values are between [ $-\infty$ to 1$]$, (Dezetter, 2008).

\section{Results}

\subsection{Variability of interannual rainfall on the watersheds} of Ouémé at Béterou and Ouémé at Bonou

The analyse of the evolution of annual rainfall in the areas of this study (Fig. 2) reveals the positive rainfall indices characterize wet periods or sequences, while negative value indices indicate periods of drought in the study environment.
Among the years corresponding to the wet sequences, there are 1963,1968, 1978, 1990, 2002 and 2010. As for the years marked by drought, there are 1971, 1974 1976, 1983, 1987, 1989. These observations have been highlighted by many studies over the study area (Le Barbé et al., 1993; Amoussou et al., 2015).

In addition, the analysis of the rupture in pluviometric stationarity revealed by the Pettitt's non-parametric method and Hubert's segmentation of Hubert, a rupture in 1987, dividing the series into two homogeneous sub-periods (1971-1987 and 1993-2010) in the two sub-basins. Thus, in the Ouémé basin at Bétérou, the 1971-1987 sub-period recorded an average annual rainfall of $1091 \mathrm{~mm}$ against $1202 \mathrm{~mm}$ over the 1988-2010 sub-period. This observation leads us to say that the 1971-1987 sub-period is pluviometrically deficient compared to the 1988-2010 sub-period, i.e. an increase of $10 \%$. Similar situations are observed in Bonou between the two sub-periods, with an increase in heights of more than $15 \%$ during the last sub-period. This situation can have repercussions on hydrological dynamics, activities and uses related to water in the study area.

\subsection{Variability of interannual flows in the Ouémé Basin at Bétérou and at Bonou}

Both at the Ouémé-Bétérou watershed and at the OuéméBonou watershed (Fig. 3), the annual flow variability is marked by wet periods illustrated by positive anomalies in 1973, 1991, 2010 while the negative anomalies explain the deficit years of water flows during the years 1974, 1977, 1983, 1987, 1989, 2005. Moreover, the rainfall rupture is taken into account to better analyzing at the impact of this rainfall variability on flows in the study area. Indeed, it is found at Ouémé-Bétérou that the average annual flows in the sub-period 1971-1987 are $47.5 \mathrm{~m}^{3} \mathrm{~s}^{-1}$ while those in the sub-period 1988-2010 are $54.5 \mathrm{~m}^{3} \mathrm{~s}^{-1}$, an increase of $14.8 \%$. As in the watershed at Ouémé-Bétérou, it is also noted in the Ouémé-Bonou's watershed that the subperiod $1971-1987\left(111 \mathrm{~m}^{3} \mathrm{~s}^{-1}\right)$ is hydrologically deficit in the 1988-2010 $\left(200 \mathrm{~m}^{3} \mathrm{~s}^{-1}\right)$ with a difference of $78.3 \%$.

Based on these results, it should be noted that rainfall variability has impacted the average flow in the study area, as already studied by Totin et al. (2016). This finding is consistent with previous studies by Mahé et al. (1995), who indicated that from the 1990s, there is a slight recovery of rainfall in West Africa, in an increasingly anthropogenic environment that has led to an increase in water levels in watercourses and water bodies compared to the 1970s and 1980s, which can lead to flood events in the watershed (Amoussou et al., 2015). 


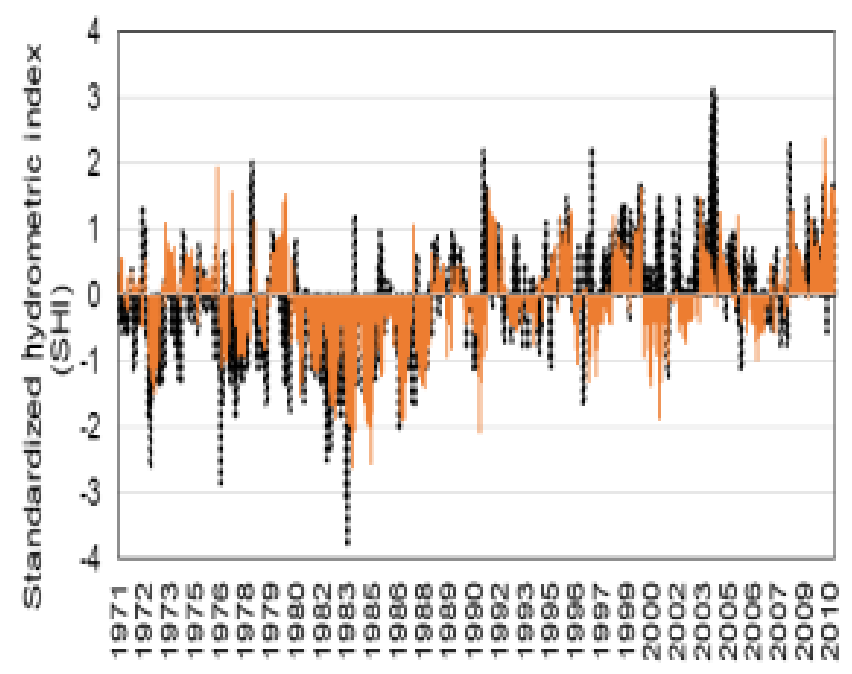

Years

\section{*SHI-Bonou ISHI-Beterou}

Figure 3. Flow index at Bétérou and Bonou (1971-2010).

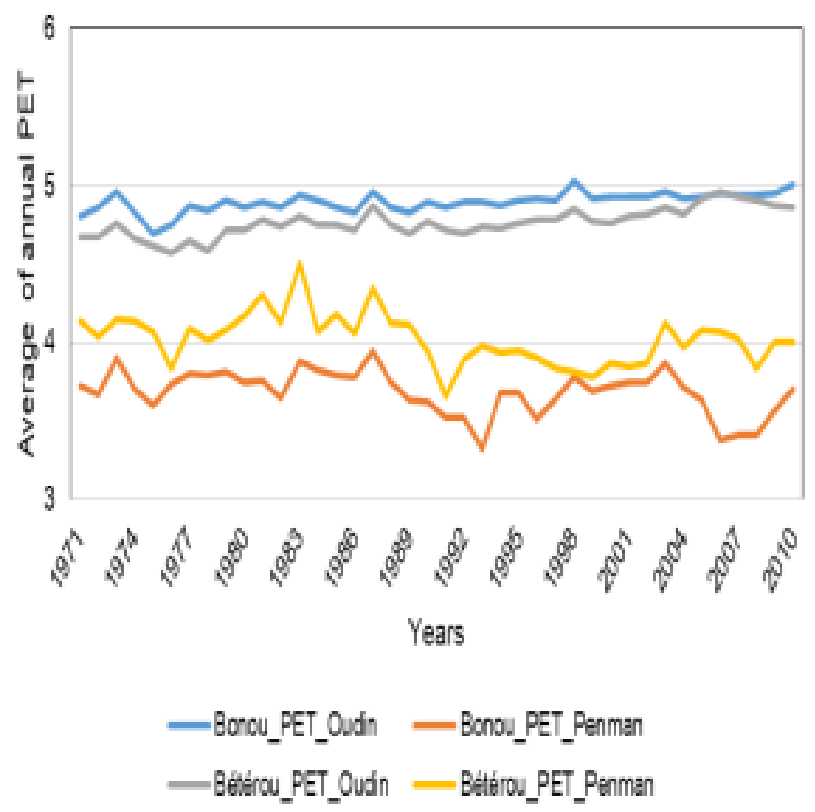

Figure 4. Comparison of annual average evolution of daily PET at Bétérou and at Bonou calculated by two methods, from 1971 to 2010.

\subsection{Interannual evolution of the average potential evapotranspiration of Penman Monteith and Oudin}

The evolution of the PET estimated by the method of Oudin has almost the same rhythm as the PET calculated with the method of Penman Monteith at Bétérou and Bonou (Fig. 4).

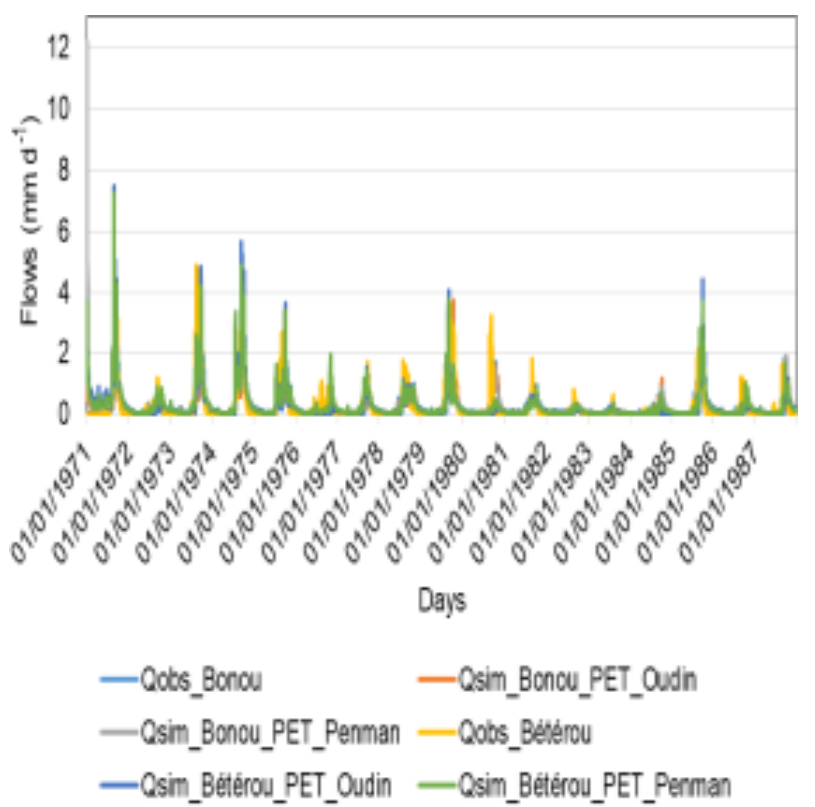

Figure 5. Observed and simulated flow variability for GR4J model calibration with Oudin and Penman PET.

Moreover, on the 1971-2010 series, the annual average of the PET at Béterrou is $4.8 \mathrm{~mm} \mathrm{~d}^{-1}$ for Oudin method while that of Penman Monteith is $4.0 \mathrm{~m} \mathrm{~d}^{-1}$ at Bétérou. As for Bonou, the PET average of Oudin method is $4.9 \mathrm{~mm} \mathrm{~d}^{-1}$ while that of Penman Monteith is $3.7 \mathrm{~mm} \mathrm{~d}^{-1}$. In addition, the discrepancies between the Oudin and Penman-Monteith PET are respectively $-15.6 \%$ at Bétérou and $-24.7 \%$ at Bonou. It is therefore appropriate for this analysis to say that for the two sub-basins the Oudin method of PET calculation underestimates the PET value in comparison of the PET of Penman-Monteith method.

\subsection{Variability of the flows observed, simulated and calibrated by the GR4J model with the PET estimated by the Oudin and Penman-Monteith methods}

The variability of the flows of observed and simulated for calibration with PET using the Oudin and Penman-Monteith methods by the GR4J model (Fig. 5), have almost the same rhythm as both Bonou and Bétérou.

However, the analysis of the biases reveals between the observed and simulated flows a difference of $8.1 \%$ and $15.5 \%$ respectively with the flows simulated with the Oudin and Penman-Monteith PET. It is the same for the simulated flow rates at Bétérou, giving a spread of $3.1 \%$ with Oudin PET and $7.3 \%$ with the Penman-Monteith PET. As already found by Amoussou et al. (2015), we can conclude that Oudin PET allows a flow simulation with a smaller bias than the PenmanMonteith PET 
Table 1. Nash values with Oudin and Penman Monteith PET.

\begin{tabular}{|c|c|c|c|c|c|c|}
\hline \multirow{2}{*}{$\begin{array}{l}\text { PET } \\
\text { Subperiods }\end{array}$} & \multicolumn{3}{|c|}{ Oudin } & \multicolumn{3}{|c|}{ Penman Monteih } \\
\hline & $\mathrm{NSE} \sqrt{ } Q$ & $\operatorname{NSE}(\ln (Q))$ & $\operatorname{NSE}(Q)$ & $\mathrm{NSE} \sqrt{ } Q$ & $\mathrm{NSE}(\ln (Q))$ & $\operatorname{NSE}(Q)$ \\
\hline \multicolumn{7}{|c|}{ Ouémé at Bonou } \\
\hline Cal_71-87 (DP) & 0.91 & 0.83 & 0.83 & 0.91 & 0.83 & 0.83 \\
\hline Val_93-10 (WP) & 0.88 & 0.56 & 0.76 & 0.87 & 0.56 & 0.76 \\
\hline Cal_93-10 (WP) & 0.90 & 0.90 & 0.85 & 0.90 & 0.90 & 0.85 \\
\hline Val_71-87 (DP) & 0.85 & 0.60 & 0.75 & 0.85 & 0.60 & 0.75 \\
\hline \multicolumn{7}{|c|}{ Ouémé at Bétérou } \\
\hline Cal_71-87 (DP) & 0.64 & 0.70 & 0.52 & 0.64 & 0.70 & 0.52 \\
\hline Val_93-10 (WP) & 0.75 & 0.78 & 0.59 & 0.75 & 0.78 & 0.59 \\
\hline Cal_93-10 (WP) & 0.78 & 0.79 & 0.61 & 0.78 & 0.79 & 0.61 \\
\hline Val_71-87 (DP) & 0.61 & 0.70 & 0.49 & 0.61 & 0.70 & 0.49 \\
\hline
\end{tabular}

$\mathrm{DP}=$ Dry Period; $\mathrm{WP}=$ Humid Period.

However, optimization criteria of the model is also an indicator to better appreciate the model's performance, the calibration of the GR4J model from potential evapotranspiration estimates, including the Penman-Monteith and Oudin PET in the basin.

\subsection{Values of calibration criteria and validation with the GR4J model in the catchment areas of Ouémé at Bétérou and Ouémé at Bonou}

The results show that the values of Nash (NSE) calculated on the square roots of the flows, on the logarithms of the flows and on the high water flows in the watersheds of Ouémé at Bétérou and Ouémé at Bonou, give the same values corresponding to each criterion for both the Oudin PET and the Penman Monteith PET (Table 1).

Furthermore, Evapotranspiration (PET) is an important process in the water cycle. However, despite the difference between Oudin's PET and Penman-Monteith's PET reported on the analysis of Figs. 4 and 5, it is observed that the formulations of these PET do not have as much influence on the values of the Nash in calibration (in dry period the values of Nash vary from 0.83 to 0.91 at Bonou and from 0.52 to 0.70 at Bétérou) as in validation (Nash vary from 0.56 to 0.88 at Bonou and from 0.59 to 0.78 at Bétérou) with the GR4J model on the two sub-watersheds, under different rainfall regimes (Le Barbé et al., 1993). This result is similar to the work of Dezetter (1991); Oudin et al. (2005) and recently Ben Khediri and Drugs (2015); Dallaire (2019). They demonstrated that the rainfall-runoff models that use PET as input are not much sensitive to the estimation method of the PET calculation for the model performance.

\section{Conclusions}

Despite a great variability between the two different formulations of PET Oudin and Penman-Monteith used in this research, it should be noted that the results show the similar trends with the Nash values. Thus, it should be concluded that the formulation of PET has few impacts on the results of the GR4J model for these tropical basins. However, in the context of global changes, and in particular the changes that the area of study is facing, this result must be taken into account in the analysis of current hydrological processes and the revision of hydrological standards in tropical basins.

Data availability. The data are not publicly accessible: The climatological data are the properties of the National Directorate of Meteorology (NDM) at Cotonou in Benin, and an Environmental System of Information on Water Resource and Modeling (SIEREM)/HydroSciences Montpellier (HSM), UMR 5569. The hydrometric data, are the properties of the Directorate General of Water (DGEau)/Benin and an Environmental System of Information on Water Resource and Modeling (SIEREM)/HydroSciences Montpellier (HSM), UMR 5569.

Author contributions. All of the authors contributed effectively to the collection, processing and analysis of the data. They also contributed to the writing and proofreading of the paper.

Competing interests. The authors declare that they have no conflict of interest. 
Special issue statement. This article is part of the special issue "Hydrological processes and water security in a changing world". It is a result of the 8th Global FRIEND-Water Conference: Hydrological Processes and Water Security in a Changing World, Beijing, China, 6-9 November 2018.

Acknowledgements. The Authors thank the organizers of 8th Global FRIEND-Water Conference and IHP-UNESCO. The Authors also thank the Benin Weather Agency and the SIEREM/HSM database for providing the data. The authors would also like to thank the reviewers of this paper.

\section{References}

Afouda, A., Aguè, A. I., and Lanhoussi, F.: Etude comparative d'un modèle conceptuel global (GR4J) et d'un modèle semi-distribue (GEOSFM) sur le bassin versant de l'Ouémé à Savè (Bénin, Afrique de l'Ouest), Revue LJEE, 24-25, 2015.

Allen, R. G., Pereira, L. S., Raes, D., and Smith, M.: Crop evapotranspiration- Guidelines for computing crop water requirements-FAO Irrigation and drainage paper 56, Rome, Italy $15 \mathrm{pp}, 1998$.

Amoussou, E., Totin Vodounon, H., Houessou, S., Tramblay, Y., Camberlin, P., Houndenou, C., Boko, M., Mahe, G., and Paturel, J. E.: Application d'un modèle conceptuel à l'analyse de la dynamique hydrométéorologique des crues dans un bassinversant en milieu tropical humide: cas du Fleuve Mono. XXVIIIe Colloque de l'Association Internationale de Climatologie, Liège 2015, 17-24, 2015.

Andréassian, V., Perrin, C., and Michel, C.: Impact of imperfect potential evapotranspiration knowledge on the efficiency and parameters of watershed models, J. Hydrol., 286, 19-35, 2004.

Ben Khediri, W. and Drogue, G.: Quel est l'impact de l'échantillonnage spatial des précipitations et de l'évapotranspiration potentielle sur le pouvoir prédictif d'un modèle hydrologique empirique?, Climatologie, 12, 24 pp., 2015.

Boyer, J. F., Dieulin, C., Rouché, N., Crès, A., Servat, E., Paturel, J. E., and Mahé, G.: SIEREM: an environmental information system for water resources, in: Water Resource Variability: Hydrological Impacts. Proc. of the 5th FRIEND World Conference, La Havana, Cuba, IAHS Publ., 308, 19-25, 2006.

Crétat, J., Richard, Y., Pohl, B., Rouault, M., Reason, C. J. C., and Fauchereau, N.: Recurrent daily rainfall patterns over South Africa and associated dynamics during the core of the austral summer, Int. J. Climatol., 2, 261-273, 2012.

Dallaire, G.: Étude de l'incertitude liée à la modélisation de l'évapotranspiration potentielle dans les études d'impact des changements climatiques sur les ressources en eau au Canada, aux États-Unis et au Mexique, Doctoral dissertation, École de Technologie Supérieure de Québec, 144 pp., 2019.
Dezetter, A.: Modélisation globale de la relation pluie débit. Application en zone de savanes soudanaises (Nord-Ouest de la Côte d'Ivoire), Thèse de Doctrat, Université de Montpellier II, France, 428 pp., 1991.

Dezetter, A., Girard, S., Paturel, J. E., Mahé, G., Ardoin-Bardin, S., and Servat, E.: Simulation of runoff in West Africa: Is there a single data-model combination that produces the best simulation results?, J. Hydrol., 354, 203-212, 2008.

Kay, A. L. and Davies, H. N.: Calculating potential evaporation from climate model data: A source of uncertainty for hydrological climate change impacts, J. Hydrol., 358, 221-239, 2008.

Le Barbé, L., Alé, G., Millet, B., Texier, H., Borel, Y., and Gualde, R.: Les ressources en eaux superficielles de la République du Bénin, Edition ORSTOM, 540 pp., 1993.

Mahé, G. and Olivry, J. C.: Variations des précipitations et des écoulements en Afrique de l'Ouest et Centrale de 1951 à 1989, Sécheresse, 6, 109-117, 1995.

Nash, J. E. and Sutcliffe, J. V.: River flow forecasting through conceptual models, Part I - A discussion of principles, J. Hydrol., 10, 282-290, 1970.

Oudin, L.: Recherche d'un modèle d'évapotranspiration potentielle pertinent comme entrée d'un modèle pluie-débit global, Thèse de doctorat, ENGREF (AgroParisTech), 496 pp, 2004.

Oudin, L., Hervieu, F., Michel, C., Perrin, C., Andréassian, V., Anctil, F., and Loumagne, C.: Which potential evapotranspiration input for a lumped rainfall-runoff model?: Part 2 - Towards a simple and efficient potential evapotranspiration model for rainfallrunoff modelling, J. Hydrol., 303, 290-306, 2005.

Paturel, J. E., Ouedraogo, M., Mahe, G., Servat, E., Dezetter, A., and Ardoin, S.: The influence of distributed input data on the hydrological modelling of monthly river flow regimes in West Africa, Hydrol. Sci. J., 48, 881-890, 2003.

Perrin, C., Michel, C., and Andreassian, V.: Improvement of a parsimonious model for stream flow simulation, J. Hydrol., 279, 275 289, 2003.

Sighomnou, D.: Analyse et redéfinition des régimes climatiques et hydrologiques du Cameroun : perspectives d'évolution des ressources en eau, Yaoundé: Université de Yaoundé 1, multigr. Th.: Sci. de l'Eau, Université de Yaoundé, 1, 289 pp., 2004.

Totin, V. S. H., Amoussou, E., Odoulami, L., Boko, M., and Blivi, B. A.: Seuils pluviométriques des niveaux de risque d'inondation dans le bassin de l'Ouémé au Bénin (Afrique de l'Ouest), in: Actes de Colloque de l'Association Internationale de Climatologie, Besançon, 369-374, 2016.

Vissin, E. W.: Impact de la variabilité climatique et de la dynamique des états de surface sur les écoulements du bassin béninois du fleuve Niger, Thèse de Doctorat de l'Université de Bourgogne, Dijon, France, 280 pp., 2007. 